\title{
SOME HISTORICAL LAYERS IN THE CUSTOMS OF ST. LAWRENCE'S DAY
}

\section{Mall Hiiemäe}

\section{Laurits stone at an Estonian place of worship}

On 10 August 258 A.D. Deacon Laurentius, Spanish by birth, raised in Rome was tortured to death by the order of Emperor Valerianus for refusing to renounce his principles. As the legend goes, Laurentius was grilled live on an iron grid. Having been canonized a saint in the 4th century, he began to be worshipped as the patron saint of fire around the end of the 10th century, and his cult spread gradually all over Europe as far as Scandinavia (Wrede 1932/3: 924-932).

In Kuusalu parish, northern Estonia the legend about the martyr's death of St. Lawrence must have been known widely. Collectors have heard it retold even after World War II. The following information was published in the early 20th century: Rajakivi ('boundary stone'), situated between the Kuusalu pastorate and village, 1/4 versts north of the church, on the right-hand side of the road. This is a rather big stone, with a boundary-marking cross on its top surface, but a pair of scissors are carved on its northern side and an iron grid (Rost) on the southern side. The scissors and grid are said to mean that St. Laurentius, to whom Kuusalu Church is consecrated, was a martyr of old, who was cut with scissors and then grilled and burnt on an iron grid. But besides it is also an old sacrificing stone with several little cup-marks hollowed into its top surface, where sacrificial grains were laid. (Jung 1910: 85-86)

The incisions, resembling an iron grid and scissors, or fire tongs, are clearly visible on the stone even today. The grid on the stone is of the same proportions, more or less, than that depicted on icons as held by St. Lawrence, and it has a ring-shaped handle as well, only here the bars are perpendicular to the handle. If we now knew for sure the actual purpose of the carvings, it would certainly lead us closer to the guessing of the date of their origin.

As we know, Kuusalu parish was established in 1220, which is very soon after the Danish conquest of the area in the winter of 1219. It is not unlikely that a Cistercian monastic estate was also founded there in the 13th century. Up to 1519 the local villages belonged to the Monastery of Ruma (Johansen 1933: 368-370). Consequently, the image reminiscent of fire tongs or scissors need not actually derive from the legend of St. Lawrence at all. Instead, it may depict, for example, two crosiers crossed, as the stone may well carry the emblem of the church, or the boundary mark of the Cistercian lands, like the one on the signet of the monastery in Gotland.

Yet from the point of view of the present study the cup-marks are even more interesting as they make Lauritsakivi 'Laurits stone' or Rajakivi a blending example of Christian and pagan traditions. There are also reports of another, smaller stone with cup-marks, lying nearby, and of an eye-healing spring being situated just a few dozen meters off the spot (Hermann 1973: 347).

Although in 1983 I could not find either the smaller stone or the spring, it is notable that mass gatherings at Kuusalu Church on St. Lawrence's Day have persisted right into the 20th century, which is rather untypical of the Lutheran Estonians.

Thousands of people from near and far are reported to have come to church on that particular day and participate in the following celebrations (Tampere 1938: 3). According to several reports kept in the Folklore Archives, the rally would drain the nearby estates of labour just at the height of the 
precious harvesting time. Even those landlords whose lands lay outside the parish, were unable to keep their peasants back from going to Kuusalu:

Every St. Lawrence's Day a sermon is held at Kuusalu (probably to commemorate the builder of the church). It is told that a few dozen years ago all of the parish folks had gone to church, but the Kännu lord of Kolga did not let the people of the parish and his own peasants go, as the day had been planned for sheltering rye. A farm hand protested, "Why, all masters let their servants go on holiday today, why not us?" That question earned the man sixty strokes with switches: Now get to work, you lazy one! Yet, when most of the sheaves were under shelter, a black cloud rose up in the sky. A thunderstorm broke out and raged around something terrible in the manor lord's field. What sheaves had still remained in the field, were torn apart, so that they rolled about in the storm and the grains got beaten out altogether. Then lightning struck the barn. The lord of the manor was left without any rye that year. Then he said, "Was I but a fool. God will ever have more power than I have." (E 7455 (12) < Kadrina, 1897)

Could it not be surmised that the tradition of late summer gatherings held at the centre of Kuusalu dates back to times before the Danish conquest? In this case the building of a church named after St. Lawrence in the vicinity of the traditional meeting place could sanction those gatherings since the 13th century. If so, it must have favored the legend of the burning of St. Lawrence being associated with the sacrificial stone, and the interpretation of the carvings as attributes of the burning act. Later on the working ban and the gatherings may have attracted additional motives. As for sowing, the gatherings could have served to celebrate it ever since rye began to be cultivated, as rye is usually sown just about that time. Indeed, excavating at Kuusalu, archeologists have found a considerable amount of charred grain lying in the base layer of the 11th century bog fort of Pajulinna, that is likely to have been permanently inhabited at that time. (Tõnisson 1982: 317)

Cup-marked sacrificial stones discovered in Estonia are generally believed to date back to the Early Iron Age (6th cent. B.C. - 1st cent. A.D.). As for the region of Kuusalu, there is such a stone at Kiiu, $3 \mathrm{~km}$ west of Kuusalu, and another at Valkla, ab. $5 \mathrm{~km}$ westwards. Ten $\mathrm{km}$ north-east of Kuusalu there is a unique burial-place of the Early Iron Age containing ab. 100 burials (instead of the usual dozen). This leads us to believe that the Muuksi stone cist grave belonged to a community rather than a large family, which is indicative of a permanent settlement of land-cultivators. (Lougas 1982: 177; 185; 200-201).

Considering the whole area where cup-marked stones have ever been found (Denmark, northern Germany, Scandinavia, northern Estonia), the Kuusalu site of worship could be dated even as early as B.C. The grounds for believing that mass gatherings have been regular for over 2000 years, dating back to the Late Bronze Age (esp. the Asva culture, cf. Lõugas 1982: 158-159), and that one of them always fell on late summer, are perhaps not solid enough, and yet the idea does not seem quite illogical.

The positive arguments read as follows:

1. the milder climatic characteristics of the coastal regions of Estonia created a relatively favorable background for the development of primitive land cultivation;

2. there were good conditions for communication seaways;

3. the community way of life, which was based on common property, must have facilitated coordination of activities; 4) the region is relatively rich in archaeological finds. 
A rye-sowing term St. Lawrence's Day is a church calendar date well suited to be taken over by the folk calendar as a late-summer term of harvesting and of sowing winter crops. The same has actually happened in Sweden and in Finland (Schön 1982: 94; Vilkuna 1968: 207-208).

There are also some phenological sowing-markers, whose earlier importance was certainly much greater than implied by the remains of folk tradition collected over the past hundred years. In Estonia such phenomena as the blooming of heather, the departing flight of the so-called sowing cranes, the appearance of gossamer etc. all occur practically within two months. Of the dates of the church calendar there are several that have acquired a permanent relation to sowing: St. Lawrence's Day (10 August), Assumption of the Virgin Day (15 August, all Estonian names for it containing the component rukki- 'rye' GenSg, or külvi- 'sowing' GenSg), St. Bartholomew's Day (24 August), Florian Day (18 August, known by the Greek-Orthodox Setu people as rollapäev, dedicated to martyr Florus). It would hardly be reasonable to argue that before those dates became fixed, the ancient Estonians had either one universal Sowing Day (or several of such), or nothing regular at all. More likely than not some conventional terms were agreed upon on a regional group level (e.g. family, community). As for sowing, those dates may well have been as follows:

1. a day of preventive magic,

2. the first day of real sowing,

3. one or more intermediate days with a working ban,

4. the last day of sowing etc.

Sacrificial rites could belong to any of them. Later all those meanings and functions were gradually attached to certain dates of the church calendar. But those dates have not remained immune to change either, developing, as time passed, many a regional difference.

The function of marking sowing-time is fixed firmly to St. Lawrence's Day in the northern and especially in the western part of Estonia (Tampere 1965: 218). This is revealed by mapping the data of the Folklore Archives, the materials of which are not much older than a hundred years. If we complement the map with ethnographic records from the Estonian Folk Museum and the relevant reports collected by the Folklore Department of the Literary Museum, we can see that there is scattered evidence of the marking function of the day being also spread in southern Estonia, but the tradition appears to have levelled towards the Assumption of the Virgin Day, which is temporally more central.

In those reports St. Lawrence's Day is usually mentioned either in connection with the first or the best day for sowing. Often, resp. in western Estonia taboos are mentioned, warning that to sow on that particular day would mean poor crops (chaffy grain, summer droughts, thistles in the rye). Instead, it is recommended to start sowing either three days before or after St. Lawrence's Day, to ensure that rye would yield the best possible crops. In northern Estonia it is predominantly believed that old seed should be sown before and new seed after St. Lawrence's Day.

The observance of a middle term could be motivated by the Germanic idea of a special Mother Day of Rye being critical to next year's crops. As for neighboring peoples, the taboo aspect is salient in the Latvian tradition. There it was considered wrong to mow or tear grass (otherwise it would stop growing), to cut down trees (it is allowed to cut alder brush, though, in order to eliminate it more effectively), or to pick fruit in the garden (otherwise the trees would lose their growing power) on that day (Smits 1940: 998).

As for Estonians, they have retained their rye-sowing beliefs throughout centuries, doing it relatively independently from St. Lawrence and his patronage. Notably, St. Lawrence's Day was the 
main term of rye-sowing for those Estonians who belonged to the united cultural area of central Sweden, the southern and south-eastern parts of Finland, and the coastal part of western and northern Estonia (cf. Lõugas 1982: 201). In Estonia the borderline of this area lies in the northeastern - south-western direction (along the Narva-Pärnu line) and is discernible in many maps of folklore.

\section{St. Lawrence as the patron saint of horses}

As appears from the Estonian folklore, St. Lawrence's Day can hardly be called a herdsman's holiday. Yet there is a layer in the day's customs that concerns domestic animals, especially horses. Reports to this effect can be found both in historical and in folklore files. There is a case record of 1695 according to which some peasants of Vastseliina and Rõuge parishes (south-eastern Estonia) had dealt with "idol-worshipping" and celebrated "Laurits' holiday" (Öpik 1980: 97-100). According to a witness the sacrificing act was accompanied by the walking of horses while the men prayed, "Holy Laurits, do please help us, our cattle, our horses," etc. The horses were covered with wax and candles, a black rooster was killed.

The problem how St. Lawrence could become a patron of horses could be explained as follows: culturally south-eastern Estonia belongs to the domain of the Greek-Orthodox Church. In their iconographic tradition the saints Flor and Lavr are depicted on horseback. August 18 is dedicated to those two martyrs Florus and Lauros. True, the case record mentions August 10, which is a date of the Catholic church calendar. Moreover, the day is called Laurits' holiday and the prayers are addressed to "Holy Laurits". It does not appear from this, however, whether St. Lawrence's patronage of horses was spread any more widely, or whether the case was just one of occasional contamination.

This problem can be illuminated by the help of the materials concerning Estonian folk calendar, that are kept at the Folklore Archives. In the Orthodox Setu area a horses' holiday is observed, as mentioned above, on 18 August, but its names rollapäev, troll derive from Flor, not Lavr (a metathetic form Frol has spread into Russian usage as well). The Votian adaption sounds hlaar or laar, while the origin of the name may lie with both saints at the same time. This is a sheer horses' holiday indeed (Ariste 1969: 116-121; Ränk 1960: 9 ff). According to a report from Vaivara, which is a parish in north-eastern Estonia, with a distinctive Votian element, horses' holiday is associated with St. Lawrence's Day:

In Kuterküla no horse could be harnessed, or lent out, or exploited in any other way on St. Lawrence's Day. Whoever violated the rule ran the risk of the horse being taken ill or dying. Reason: Once a horses' pest had afflicted Kuterküla; no doctors could help. Then the people had turned to the local wizard. The wizard recommended that the horses should be given a holiday. This done, the horses recovered. Another time (a few years ago, they say) a man had given his horse to the manor's lord to ride on St. Lawrence's Day. The same evening a wolf had attacked the horse, quite near home, and torn it so that the horse died. (The tradition is still alive). (H II 1, 672 (16) < Vaivara, 1888)

The slight tendency of St. Lawrence's patronage extending to cover some cattle as well is not really surprising. According to some reports from southern Estonia a black rooster would be sacrificed or eaten in horse stables and to the horses' luck on some other days as well, especially on St. George's Day and on Michaelmas. On Midsummer Eve it is sought to make cattle thrive by walking them round the bonfire. There is also an undated note of South-Estonian origin: Oxen were not put to yoke on St. Lawrence's Day, as otherwise their horns would wear and break. (E 8 9, $37(115)<$ Rõngu; Sangaste) 
According to church visitation records and the materials of the Folklore Archives, sacrificing on St. Lawrence's Day, or near chapels consecrated to St. Lawrence was practised in several places, mostly in southern Estonia, but not only there. There are numerous reports of folklorists being told that animals were killed on special days in late summer, beginning with St. Ann's Day (July 26) in south-eastern Estonia, or St. Olaf's Day (July 29) in western Estonia. In southern Estonia St. Lawrence's Day was one of the dates fixed for slaughtering he-goats and sheep. Hence the proverb: Laurits tuleb, laud seljas, Pärtel tuleb, puss peos ('Lawrence will come with a board on his back, Bartholomew will come with a knife in his hand'). Although the reference is apparently made to the attributes carried by those saints on icons - the grid of St. Lawrence and the nail of crucifixion of St. Bartholomew - what we actually have here is a case of personification of the names of certain dates in the calendar.

There is hardly any reason to assume that all information of sacrifices being offered or animals being slaughtered was associated with cattle magic, as far as the descriptions available are void of any such motivation. In southern Estonia St. Lawrence's Day celebrations are in addition connected with new crops (vegetables, fruits, legumes), thus acquiring some traits of a harvest festival. This, however, should not disturb us from considering the day having served as a sowing term in northern and western Estonia, as the beliefs are really distant from each other.

\section{Do Estonians have a God of Fire?}

The repute of St.Lawrence as a patron saint of fire was established mainly in western and southern Estonia. This was manifested as the ban on heating the kiln for drying grain and on threshing grain on his name day. The ban was motivated by fire risks:

On St. Lawrence's Day one never heated the oven, or cooked; indeed, no fire was made anywhere, otherwise a damaging fire was imminent. Even fire irons were buried into the bases of windmills and into stone fences on that day. (E 27632 (32) < Pöide, 1896)

In western Estonia, where St. Lawrence's Day is both a sowing term and a day for enhanced fire risks, one of the motives for the working ban is a risk for the next year's crops. The warnings are as follows: no grain-threshing, otherwise the grain will shed the next year; grain should not be threshed by firelight, otherwise the crops will fail; no fire should be lit in the house, otherwise the oxen will go bolting; the grain threshed in St. Lawrence's morning will be eaten by worms (probably larvae of the dart moth were meant); in the field straw should not be collected, otherwise the grain will take fire; fire should not be lit in the kiln, otherwise the crops will be blighted. Of all sowing terms only St. Lawrence's Day bears an association with fire. On the Isle of Kihnu it was even said that fire-making is forbidden on St. Lawrence's Day as it is the name day of Fire.

As compared with the relevant beliefs of other nations, Estonians have not copied the idea of using the so-called St. Lawrence's coals as a means of magic, neither do they associate the day with the shower of 'stars' (resp. meteors) typical of August nights. And unlike the western peoples, Estonians do not consider St. Lawrence the patron saint of occupations connected with fire. The proverb Laurits laotab lehti, Pärtel pöörab päid" ('Lawrence spreads the leaves, Bartholomew turns the heads') that applies to cabbage-growing, speaks of the day as a temporal marker, not of a person.

Wherever beliefs connected with fire were held, this day was associated with an imitational-magical act of throwing water onto roofs. (This was the preventive activity practised any day as soon as an ominous glow of fire was noticed.) In southern Estonia, near the Latvian border a bath-whisk and a bucket with water were placed on the oven mouth so that "Labrits" could whisk himself. As for Latvians, their tradition of such beliefs is still richer: the one who wants to heat an oven on St. 
Lawrence's Day should bring two buckets of water and a bath whisk either to the drying barn or to the oven; as Laurentius was baked on fire, fire should not be made; one of the names for the day was uguns diena ('the day of fire') (Smits 1940: 994-997).

There is a fabulous legend of a miraculous case of grain-thrashing, known mostly in southern Estonia. According to Aarne-Thompson's Catalogue it is current in the Finnish, Swedish, Estonian, Livonian, Lithuanian, Catalan, Flemish, German, Italian, Rumanian, Hungarian, Czech, Slovenian and Serbo-Croatian traditions. The Estonian variants may be centered either around Jesus with his disciples, St. Peter, St. Lawrence, Moses, or just an old man. The following text, however, tells of Laurits and the events take place on St. Lawrence's Day.

\section{Laurits}

Grandfather said that he had seen with his own eye how Laurits threshed grain. It had been a morning of St. Lawrence's Day. The master wanted to go threshing, but the mistress said, "Don't go, today is St. Lawrence's Day, no grain-threshing is done today." The master replied, "The oven is heated, the grain is dry, the floor is clean - when else should I do the threshing?" So the master was complaining. Then there came a man and said, "I am Laurits. I'm going to thresh your grain for you today."

The master said, How could you do it alone, and in them good clothes you are wearing?" - "Don't worry, I'll see to it that everything will be done all right." So the man kept insisting until they went and took the grain down. The stranger had it all taken to the threshing-room. Then he set it alight. The master exclaimed, "Good heavens, now you're going to burn down the house and the grain with it!" But the stranger said, "Don't you worry. You'll only be thankful to me for threshing your grain for you. Then he started walking around the pile, saying, "Hush, Laurits, hush! Don't you hop onto the rooftop!" And the fire grew less and didn't hop anywhere. And the master sat on the threshold, watching. And the straw went to the barn and the seeds went into the corner of the threshing-room all by themselves. Then the stranger said, "Well, Laurits, now you skin the seed and send the chaff to the store-room." And so the seed came out clean and the chaff did go to the storeroom, while the man was just standing idle, not doing anything. Finally he said, "Well, Master, now everything is ready and the grain threshed. What do you say to it?" - "Well, thanks a lot. How much do I owe to you?" - "Nothing. I just wanted to show you the way Laurits threshes grain." Then they invited the man to lunch, but he did not eat anything, saying, "There's a spell cast on it." Leaving, he told the master, "You call me again, if you need help. But if you should ever try threshing this way on your own, you'll burn everything down." A neighbor came. "Hello, master! Who was the young gentleman?" The master said it was Laurits and explained what he had done. The neighbor went and set his own barn on fire. Although he kept saying, "Laurits, hush! Don't you hop onto the rooftop." But the fire spread on to the loft and rooftop, burning everything down. (ERA II 63, $82 /(182)<$ Põlva, 1933)

Sometimes the text is complemented with an intimation that this is why making fire is forbidden on St. Lawrence's Day. The phrase "Laurits, don't go to the loft!" was used separately as a fire spell. In older literary sources the fact that making fire was forbidden on St. Lawrence's Day occurs several times. Religious studies have led scholars to asking, whether Estonians had an image of a guardian spirit of fire before the advent of Christianity, or whether they got it from Catholic monks, or perhaps they even worshipped a God of Fire (Eisen 1918/9: 225; Eisen 1920: 114), or practised a cult of fire (Loorits 1957: 51-63). Here it should first be pointed out that the meaning of the 
Estonian word jumal 'God' is broad enough to encompass the notions of a guardian spirit or patron. Consequently the Feuergott Laurits of older German sources (e.g. Hupel 1777: 145) should not be interpreted as a monotheistically sounding God (of Fire), but rather - at least in the present case concerning southern Estonia, northern Latvia, and Livonia - a guardian spirit of fire.

The fact that in the Estonian Laurits tradition the main attention is focused on fire risks to buildings makes one think of the ancient technologies of grain drying. It is not unlikely that at that season of the year the fire risk to the chimneyless buildings used for drying grain was quite considerable. A fire could easily destroy he whole property and leave the family homeless. Hence, there is reason to believe that a sharpened sense of fire risks developing at harvesting time, appropriate methods of preventive magic and taboos culminated at the period when fields began to be cultivated on a longterm basis and farm houses, including barns for grain-drying began to be built.

Consequently, St. Lawrence as the patron saint of fire, who became popular in western Europe (Germany, Belgium, the Netherlands, Poland) in the 10th century A.D., had a good chance to enter the ideology of the Estonian people before their Christianizing, while the image could have travelled by land as well as by sea. This was a survey of the possible history of St. Lawrence's Day in Estonia. Today the traditions, handed down from generation to generation for many centuries, are well on their way to oblivion, being manifested just by a few fragments in the memories of elderly people.

Translated by Sirje Ainsaar

\section{Literature}

Aarne, A. \& Thompson, S. 1961. The Types of the Folktale. A Classification and Bibliography. FFC 184. Helsinki.

Ariste, P. 1969. Vadja rahvakalender. Tallinn.

Eisen, M. J. 1920. Esivanemate ohverdamised. Eesti mütoloogia III. Tallinn.

Eisen, M. J. 1918/9. Tulekultus. I. Eesti Kirjandus, nr 10, pp. 225-226.

Hermann, U. 1973. Kuusalu Lauritsakivi ja silmaallikas. I. Eesti Loodus, nr 6, p. 347.

Hiiemäe, M. 1991. Eesti rahvakalender.V. Tallinn.

Hupel, A. W. 1777; 1782. Topographische Nachrichten von Lief- und Ehstland. II, III. Riga.

Johansen, P. 1933. Die Estlandliste des Liber Census Daniae. Kopenhagen-Reval.

Jung, J. 1910. Muinasteadus eestlaste maalt. III. Kohalised muinasaja kirjeldused Tallinnamaalt.

Tartu.

Loorits, O. 1957. Grundzüge des estnischen Volksglaubens. III. Lund.

Lõugas, V. 1982. Pronksiaeg (II aastatuhande keskpaik - 7.sajand e.m.a.); Varane rauaaeg (6. saj. e.m.a.-1. sajand m.a.j.). I. Eesti esiajalugu. Tallinn, pp. 126-203.

Ränk, G. 1960. Vatjalaiset. Helsinki.

Schmiedehelm, M. 1939. Kuusalu Pajulinn. I. Muistse Eesti linnused. (Toim. H. Moora). Tartu, pp. 121-138.

Schön, E. 1989. Folktrons är. Gammalt skorck kring arsfester, märkesdagagar och fruktbaerhet. Raben \& Sjögren.

Schmiedehiedehelm, M. 1939. Kuusalu Pajulinn. I. Muistse Eesti linnused. (Toim. H. Moora). Tartu, pp. 121-138.

Schön, E. 1989. Folktrons_år. Gammalt skrock kring årsfester, märkesdagar och fruktbarhet. Raben \& Sjögren. 
Smits, P. 1940. Latvieshu tautas ticejumi. II. Riga.

Tampere, H. 1938. Vana Kannel. III. Kuusalu vanad laulud. I. Tallinn.

Tampere, H. Kirde-Eesti rahvakalendri iseärasusi I. Slaavi-läänemeresoome suhete ajaloost.

Artiklite kogumik. (Toim. H. Moora ja L. Jaanits). Tallinn, pp. 205-262.

Tõnisson, E. 1982. Noorem rauaaeg (10. sajand - 13. sajandi algus). Eesti esiajalugu.I. Tallinn, pp. 306-421.

Vilkuna, K. 1968. Vuotuinen ajantieto. Vanhoista merkkipäivistä sekä talous- ja sääkalenderista enteineen. Toinen, korjattu ja lisätty painos. Helsinki.

Wrede, A. 1932/3. Laurentius. I. Handwörterbuch des deustchen Aberglaubens. V, herausgeben unter besonderer Mitwirkung von E. Hoffmann Krayer und mitarbeitet zahlreichen Fachgenossen von Hanns Bächtold-Stäubli. Berlin \& Leipzig, pp. 924-932.

Öpik, E. 1980.Kirjeldus Lauritsa kultusest Kagu-Eestis XVII sajandi lõpul. Keel ja Kirjandus, nr 2, pp. 97-101. 